\title{
KONSTRUKSI DISTINGSI KEILMUAN PRODI PENDIDIKAN AGAMA ISLAM MELALUI PENDEKATAN INTERDISIPLINER DAN MULTIDISIPLINER PADA PROGRAM PASCASARJANA
}

\author{
Jaenullah, Mispani, Choirudin \\ Institut Agama Islam Ma'arif NU (IAIMNU) Metro Lampung \\ jaenullah@iaimnumetrolampung.ac.id \\ mispani66@gmail.com \\ choirudiniaimnumetro@gmail.com
}

\begin{abstract}
This paper discusses the construction of the scientific distinction of the Islamic study prograrm (PAI) through an interdisciplinary and multidisciplinary learning approach at the Institut Agama Islam Ma'arif NU (IAIMNU) Metro Lampung Postgraduate Program. This type of study used qualitative methods with a phenomenological approach. This research concludes firstly that the construction of the scientific distinction of the PAI Masters Program in the IAIMNU Metro Lampung Postgraduate Program has superior characteristics, namely to become educators, researchers, and practitioners who are able to design Islamic Islamic Studies curriculum based on Nusantara Islam, the second paradigm of learning interdisciplinary and multidisciplinary approaches in the Study Program. Postgraduate Program is carried out by applying the integration of interdisciplinary and multidisciplinary knowledge seen in the curriculum structure applied in the PAI Study Program, which then affects student thesis studies that are integrated with other disciplines.
\end{abstract}

Keywords: Interdisciplinary and Multidisciplinary Learning Approach, Islamic Study, Scientific Distinction Construction, Postgraduate Program

\begin{abstract}
Abstrak
Tulisan ini membahas mengenai konstruksi distingsi keilmuan Prodi PAI melalui pendekatan pembelajaran interdisipliner dan multidisipliner pada Program Pascasarjana IAIMNU Metro Lampung. Jenis penelitian yang digunakan metode kualitatif dengan pendekatan fenomenologi. Penelitian ini menyimpulkan pertama bahwa konstruksi distingsi keilmuan prodi S2 PAI Program Pascasarjana IAIMNU Metro Lampung telah memiliki karakteristik keunggulan, yaitu untuk menjadi tenaga pendidik, peneliti, dan praktisi yang mampu mendesain kurikulum PAI berbasis Islam Nusantara, kedua paradigma pembelajaran pendekatan interdisipliner dan multidisipliner pada Prodi S2 PAI dilakukan dengan pengaplikasian integrasi ilmu yang interdisipliner dan multidisipliner terlihat pada struktur kurikulum yang diterapkan di Prodi PAI, yang kemudian berpengaruh pada kajian tesis mahasiswa yang terintegrasi dengan keilmuan lain.
\end{abstract}

Kata Kunci: Konstruksi Distingsi Keilmuan, Pendidikan Agama Islam, Pendekatan Interdisipliner dan Multidisipliner, Program Pascasarjana 


\section{A. PENDahuluan}

Saat ini khususnya di negara Indonesia mengenai sistem pendidikan yang diterapkan di sekolah-sekolah ataupun di madrasah-madrasah merupakan bentuk adopsi sistemik dari sistem pendidikan Barat yang bersifat "sekuler". Dalam beberapa hal, paradigma sistem pendidikan sekuler yang mendasari sistem pendidikan di Indonesia telah bertentangan dengan nilai-nilai bangsa Indonesia sebagai bangsa yang relijius (Iriany, 2014; Musthofa, 2017; Umar, 2014). Menjadi suatu keharusan (must) khususnya bagi cendikiawan yang concern dalam bidang pendidikan untuk merekonstruksi sebuah bangunan paradigma yang dapat dijadikan dasar dalami sistem pendidikan nasional. Alternatif paradigma sistem pendidikan Islami merupakan suatu pilihan yang bijak dalam kerangka mendasari paradigma pendidikan yang didasarkan pada nilai-nilai al-Qur'an (Setyaningsih \& Subiyantoro, 2017; Subandi, 2020).

Secara historis perkembangan PTAI di negara Indonesia, sebagian besar Prodi PAI menjadi cikal bakal berdirinya pertama kali sebuah PTAI, demikian juga pada jenjang S2 dan S3 Prodi PAI selalu menjadi prodi utama dan pertama kali yang dibuka. Bahkan secara kuantitas selalu berada di atas prodi lain, atau bisa dikatakan menjadi prodi terlaris/terbanyak peminatnya di PTAI. Selain itu, Prodi Pendidikan Agama Islam dikatakan sebagai program studi yang paling fleksibel di masyarakat dan termasuk prodi yang luas, sebab dalam kajian PAI terdapat dua rumpun keilmuan yang cakupannya sangat luas, yaitu rumpun mengenai ilmu pendidikan, ilmu pendidikan Islam dan rumpun ilmu-ilmu keislaman. Dalam rumpun ilmu pendidikan terdapat cakupan ilmu pendidikan, landasan pendidikan, sejarah pendidikan, pengembangan kurikulum, metode pembelajaran, desain pembelajaran, dan evaluasi pendidikan; sedangkan dalam rumpun ilmu pendidikan Islam terdapat cakupan ilmu pendidikan Islam, filsafat pendidikan Islam, sejarah pendidikan Islam, kurikulum pendidikan Islam, dan metode pendidikan Islam; sedangkan rumpun ilmu keislaman meliputi ilmu al-Qur'an, ilmu hadits, ilmu aqidah akhlaq, ushul fiqh, fiqh, dan sejarah peradaban Islam (Jaenullah, 2018). Bahkan dalam prakteknya PAI ini masih ditambah lagi dengan materi-materi di luar materi PAI, sehingga sering kali materi intinya sering terdesak menjadi dangkal. Tentunya hal ini menjadi problem yang serius dalam penyelesaian yang strategis.

Belum selesai hiruk-pikuk akibat adanya Revolusi Industri 4.0, yang kemudian dibarengi berkembangnya era disrupsi, tiba-tiba dikejutkan dengan munculnya era Society 5.0. Baik Revolusi Industri 4.0 dan Society 5.0 menjadi sebuah gerakan yang nyata terhadap perkembangan teknologi dan informasi yang semakin canggih (Marini et al., 2020; Putra, 2019; Subandi Subandi et al., 2018; Wahyudi et al., 2021). Sehingga akibat adanya kemajuan teknologi menjadi tantangan tersendiri bagi Prodi PAI dan seluruh komponen masyarakat. Dalam rangka menghadapi berbagai macam tantangan pada era society 5.0 dibutuhkan terobosanterobosan model pendekatan inter dan multidisipliner dalam pembelajaran berbasis KKNI guna pengembangan distingsi keilmuan Prodi PAI yang paten dalam rangka upaya menghadapi tantangan yang ditimbulkan pada era society 5.0 ini. Pemilihan pendekatan interdisipliner dan multidisipliner dalam mengembangkan pembelajaran PAI pada Program Pascasarjana merupakan langkah yang tepat, sebab problem PAI selama ini dirasakan adalah ketika pembelajaran tersebut sangat berkaitan dengan materi bahan ajar. Beberapa penelitian yang relevan yang telah mengupas pendekatan pembelajaran melalui pendekatan interdisipliner dan multidisipliner antara lain penelitian yang dilakukan oleh (Azizah, 2019; Nino Indriyanto, 2019; Rahmat, 2019; Rohmatika, 2019).

\section{B. METODOLOGI PENELITIAN}

Penelitian ini menggunakan penelitian kualitatif (Creswell \& Creswell, 2017), yaitu penelitian untuk memahami fenomena tentang apa yang dialami oleh subjek penelitian, antara lain mengenai persepsi, perilaku, motivasi, tindakan, dan lain-lain, secara holistik dan dengan cara deskripsi dalam bentuk kata-kata dan bahasa, pada suatu konteks khusus yang alamiah dan dengan memanfaatkan metode alamiah (Moleong, 2014). Adapun pendekatan penelitian ini adalah fenomenologis yang bertujuan untuk mendekripsikan, mengesplorasi/menggali dan menjelaskan suatu gejala dan fakta sosial yang unik dan menarik (Sugiyono, 2017). Cara yang dilakukannya adalah dengan mendeskripsikan hal-hal yang terkait dengan problem yang ditemukan di lapangan. Adapun tujuan dari penelitian ini adalah memperoleh gambaran yang mendalam mengenai pendekatan interdisipliner dan multidisipliner dalam pembelajaran berbasis KKNI dalam rangka pengembangan distingsi keilmuan PAI. Latar penelitian ini dilaksanakan di Prodi PAI Pascasarjana IAIMNU Metro Lampung. Sampel sumber data atau informan dalam penelitian ini dilakukan dengan teknik purposive sampling, adapun yang menjadi informan dalam penelitian ini adalah Direktur, Kaprodi, dosen, dan beberapa mahasiswa pascasarjana IAIMNU Metro Lampung.

Pengumpulan data dilakukan antara lan, pertama teknik observasi yang bertujuan untuk mendapatkan data dengan melihat fakta langsung di lapangan dan memastikan kesesuaian dengan hasil wawancara, kedua, teknik wawancara dalam rangka mendapatkan data secara langsung dari sumber data yang kemudian di kumpulkan dan disusun. Dalam wawancara disusun pedoman supaya supaya tidak melebar jauh dari tujuan pengumpulan data, dan ketiga teknik dokumentasi bertujuan untuk melengkapi dari teknik yang lain. Adapun dokumen yang peneliti perlukan yaitu data Kurikulum. Kemudian teknik analisis data dilakukan dengan reduksi data, display data, dan menarik kesimpulan.

B. HASIL PENELITIAN DAN PEMBAHASAN

1. Konstruksi Distingsi Keilmuan Prodi S2 PAI Pascasarjana IAIMNU Metro Lampung Melalui Pendekatan Interdisipliner dan Multidisipliner Program Studi Magister PAI Pascasarjana IAIMNU yang saat ini sudah terakreditasi Baik dengan menggunakan 9 kriteria, memiliki visi, yaitu "Pada Tahun 2027 Menjadikan Magister S2 PAI Unggul 
Bertaraf Nasional, Berkarakter Menghasilkan Tenaga Pendidik, Peneliti, dan Praktisi/Akademisi Pendidikan di Dunia Global Yang Berlandaskan Nilai-Nilai Islam Ahli Sunnah Waljamaah An-Nahdliyah". Berdasarkan gambaran visi tersebut, maka keunggulan prodi PAI pada Program Pascasarjana IAIMNU tersebut adalah memiliki kompetensi unggul sebagai pendidik, peneliti, dan praktisi yang profesional yang berlandaskan pada Islam Ahli Sunnah Waljamaah an-Nahdliyah.

Pengembangan keilmuan Prodi PAI pada Program Pascasarjana IAIMNU Metro Lampung telah diarahkan untuk mewujudkan ciri-ciri tertentu, sehingga membentuk distingsi keilmuan yang mampu menjawab berbagai tantangan ke depannya. Distingsi keilmuan prodi PAI pada Program Pascasarjana tersebut antara lain dikemukakan oleh Direktur Pascasarjana, bahwa:
Prodi PAI yang menjadi kekhasan di Pascasarjana IAIMNU Metro Lampung adalah unggul sebagai pendidik, peneliti, dan praktisi/akademisi dalam mendesain kurikulum Pendidikan Agama Islam berbasis Islam Nusantara. Pendidikan Islam Nusantara adalah salah satu mata kuliah yang dikembangkan dan telah menjadi ciri khas Prodi Pendidikan Agama Islam di Program Pascasarjana IAIMNU Metro Lampung. (R1, Direktur, 19/12/2020)

Kemudian dari hasil wawancara dengan Ketua Prodi disebutkan bahwa dalam rangka memgembangkan distingsi keilmuan Prodi PAI di Lingkungan Pascasarjana IAIMNU telah dikembangkan rumusan kurikulum yang mengacu kepada KKNI. Adapun rumusan KKNI Program Studi Magister PAI berada pada level 8 dapat dilihat dalam tabel berikut ini.

Tabel 1

Capaian Pembelajaran Prodi Magister PAI Pascasarjana IAIMNU Metro

\begin{tabular}{|c|c|c|c|}
\hline No & $\begin{array}{l}\text { Unsur Kualifikasi } \\
\text { Kerja }\end{array}$ & Deskripsi Generik & Deskripsi Spesifik \\
\hline 1 & Kemampuan Kerja & $\begin{array}{l}\text { Mampu mengembangkan } \\
\text { pengetahuan, teknologi, } \\
\text { dan/atau seni di dalam bidang } \\
\text { keilmuannya atau praktek } \\
\text { profesionalnya melalui riset, } \\
\text { hingga menghasilkan karya } \\
\text { inovatif, dan teruji }\end{array}$ & $\begin{array}{l}\text { a. Mampu mengembangkan pengetahuan } \\
\text { dan teknologi dalam bidang ilmu } \\
\text { pendidikan agama Islam atau praktek } \\
\text { profesionalnya melalui riset, dan } \\
\text { menghasilkan karya inovatif dan } \\
\text { teruji. } \\
\text { b. Mampu memanfaatkan ilmu } \\
\text { pengetahuan dan teknologi informasi } \\
\text { dalam meningkatkan kualitas dan } \\
\text { menyelesaikan berbagai masalah } \\
\text { pembelajaran PAI }\end{array}$ \\
\hline 2 & $\begin{array}{l}\text { Penguasaan } \\
\text { Pengetahuan }\end{array}$ & 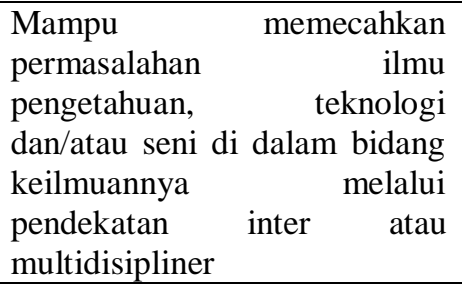 & $\begin{array}{l}\text { Mampu menganalisis dan memecahkan } \\
\text { permasalahan pembelajaran Pendidikan } \\
\text { Agama Islam melalui pendekatan inter } \\
\text { atau multidisipliner }\end{array}$ \\
\hline 3 & $\begin{array}{l}\text { Kemampuan dan } \\
\text { Tanggung Jawab } \\
\text { Manajerial }\end{array}$ & $\begin{array}{l}\text { Mampu mengelola riset dan } \\
\text { pengembangan } \\
\text { bermanfaat bagi masyarakat } \\
\text { dan keilmuan, serta mampu } \\
\text { mendapat pengakuan nasional } \\
\text { dan internasional }\end{array}$ & $\begin{array}{llr}\text { a. Mampu mengelola dan } \\
\text { mengembangkan riset yang } \\
\text { bermanfaat bagi masyarakat dan } \\
\text { keilmuan bidang PAI dan mendapat } \\
\text { pengakuan nasional dan internasional } \\
\text { b. Mampu menghasilkan dan } \\
\text { mempublikasikan karya ilmiah yang } \\
\text { inovatif dan teruji dalam bidang PAI } \\
\text { di Jurnal ilmiah nasional dan atau } \\
\text { internasional }\end{array}$ \\
\hline
\end{tabular}

Berdasarkan tabel di atas, dapatlah diambil suatu kesimpulan bahwa pendekatan pembelajaran interdisipliner dan multidisipliner menjadi salah satu pendekatan pembelajaran dalam rangka mengembangkan distingsi keilmuan untuk prodi S2 PAI Pascasarjana IAIMNU Metro Lampung. Dengan digunakannya kedua pendekatan pembelajaran tersebut diharapkan bahwa lulusan prodi Magister PAI Pascasarjana IAIMNU diharapkan memiliki kemampuan dalam memecahkan masalah yang kompleks dalam bidang Pendidikan Agama Islam berbasis Islam Nusantara.

Dilihat dari segi komposisi kurikulumnya, komposisi yang digunakan pada Prodi PAI Pascasarjana IAIMNU Metro Lampung meliputi kompetensi dasar, kompetensi utama, dan kompetensi pengembangan, dan kompetensi keterampilan. Berdasarkan data dokumentasi 
disebutkan bahwa komposisi kurikulum Prodi S2 PAI Pascasarjana IAIMNU Metro dapat dijabarkan sebagai berikut:

a. Kompetensi dasar yang berisi sejumlah mata kuliah dasar-dasar kajian Islam, mata kuliah ini meliputi antara lain: 1) Studi Al-Qur'an Hadits; 2) Studi Aqidah Akhlak; 3) Studi Fiqih Kontemporer; dan 4) Sejarah Peradaban dan Pemikiran Islam Aswaja dan Ke -NU-an

b. Kompetensi utama, yang berisi sejumlah matakuliah spesialisasi dan pembentukan keahlian bidang studi yang dikembangkan untuk mencapai tujuan program studi, mata kuliah ini meliputi: 1) Pengembangan Kurikulum PAI; 2) Pendekatan dalam Pengkajian Islam; 3) Psikologi Pendidikan Islam; 4) Metodologi dan Strategi Pembelajaran PAI; dan 5) Pengembangan Evaluasi Pembelajaran PAI

c. Kompetensi metodologi, berisi sejumlah mata kuliah dalam rangka mengembangkan kompetensi kajian ilmiah dalam konteks pengembangan ilmu pengetahuan dan teknologi serta seni dan budaya yang bernafaskan Islam sesuai dengan program studi, mata kuliah ini meliputi: 1) Metode penelitian; 2) Seminar Proposal 3) Publikasi Ilmiah; dan 4) Tesis

Kompetensi pendukung, yang berisi sejumlah mata kuliah yang dikembangkan untuk memperkuat dasar pengetahuan bidang studi utama/pokok/spesialisasinya untuk mengikuti kegiatan akademik dalam program yang lebih tinggi, mata kuliah ini adalah Pendidikan Islam Nusantara.

2. Paradigma Pembelajaran dengan Pendekatan Interdisipliner dan Multidisipliner dalam Rangka Konstruksi Distingsi Keilmuan Prodi Magister PAI Pascasarjana IAIMNU Metro Lampung

Sejak dikeluarkannya Peraturan Presiden No. 8 Tahun 2012 tentang KKNI bahwa untuk jenjang S2 atau Magister memiliki kualifikasi level 8 dimana dalam level tersebut diungkapkan indikator nya yaitu mampu memecahkan permasalahan ilmu pengetahuan, teknologi, dan/atau seni di dalam bidang keilmuannya melalui pendekatan interdisipliner atau multidisipliner. Dalam hal ini Program Pascasarjana telah melakukan beberapa kebijakan, yaitu diantaranya memberlakukan nama dan substansi mata kuliah bersifat interdisipliner sehingga memungkinkan diambil oleh mahasiswa dari berbagai bidang dan diwujudkan dalam bentuk team teaching, hal ini diungkapkan oleh Direktur Pascasarjana, bahwa:

Persoalan bidang PAI di masyarakat saat ini sangatlah kompleks, sehingga tidak cukup dengan pendekatan monodisiplin atau disiplin ilmu saja melainkan harus berbagai macam disiplin (lintas disiplin) dan multidisiplin (R1, Direktur, 19/12/2020).

Sementara itu, hasil wawancara dengan Kaprodi disebutkan bahwa:

Struktur kurikulum yang dijabarkan dalam Prodi S2 PAI telah menggunakan pendekatan integrasi interkoneksi dalam merumuskan kurikulum.
Integrasi dan interkoneksi dapat muncul mulai dari rumusan capaian pembelajaran hingga metode pembelajaran. (R2, Kaprodi, 20/12/2020).

Dalam pelaksanaannya model yang dikembangkan paradigma pembelajaran pada Prodi S2 PAI Pascasarjana IAIMNU Metro Lampung ini memiliki tiga model, yaitu Pertama, model pengintegrasian ke dalam struktur kurikulum, contoh dalam waktu 4 semester mahasiswa harus menyelesaikan bobot studi sebanyak 49 sks dengan komposisi $80 \%$ ilmu-ilmu keislaman dan keagamaan, dan 20\% ilmu-ilmu umum. Model ini sekedar untuk menyandingkan beberapa mata kuliah ilmu-ilmu keislaman atau keagamaan dan mata kuliah ilmu-ilmu umum. Proses integrasi interkoneksi keilmuannya terpusat pada bagaimana kreativitas mahasiswa dalam memahami dan menghubungkan kedua disiplin ilmu tersebut. Kedua, model penamaan mata kuliah yang menunjukkan korelasi antara ilmu keislaman dengan ilmu umum. Model ini dalam setiap nama mata kuliahnya mencantumkan kata Islam, seperti filsafat pendidikan Islam dan Psikologi Pendidikan Islam. Ketiga, model pengintegrasian ke dalam tema mata kuliah. Model ini menuntut dalam setiap pengajaran mata kuliah keislaman dan keagamaan harus disisipkan teoriteori keilmuan umum dan begitu juga sebaliknya, dalam setiap pengajaran mata kuliah ilmu-ilmu umum harus diberikan wacana teori-teori keislaman dan keagamaan sebagai wujud integrasi interkoneksi antara keduanya, tanpa embel-embel nama Islam pada mata kuliah yang bersangkutan.

Dari ketiga model pendekatan integrasi interkoneksi di atas, merupakan bagian dari pendekatan pembelajaran interdisipliner dan multidisipliner. Pendekatan interdisipliner merupakan pendekatan untuk dalam memecahkan suatu masalah dengan menggunakan perspektif berbagai sudut pandang ilmu serumpun yang relevan atau tepat guna secara terpadu (Rohmatika, 2019). Ada dua pemahaman dalam memahami pendekatan interdisipliner, yaitu: Pertama, pendekatan dengan menggunakan perspektif berbagai sudut pandang ilmu serumpun yang relevan atau tepat guna secara terpadu dalam pemecahan suatu masalah. Oleh karena itu, kata kunci pemahaman interdisipliner ini adalah ilmu yang serumpun. Ilmu yang serumpun banyak versinya. Misalnya rumpun ilmu agama, rumpun ilmu sosialhumaniora, rumpun ilmu pasti, rumpun ilmu hukum, rumpun ilmu jiwa, dan sebagainya. Kedua, interdisipliner berarti bekerja sama antara satu ilmu dengan ilmu lain sehingga menjadi satu kesatuan dengan metode tersendiri. Atau dengan kata lain integrasi antara satu ilmu dengan ilmu lain, sehingga membentuk satu ilmu baru dengan metode baru, sebagai contoh misalnya perpaduan ilmu sosiologi dan agama menjadi sosiologi agama, demikian juga dengan ilmu-ilmu lainnya (Nasution, 2017). Berikut di bawah ini bentuk pembelajaran pada prodi PAI dengan pendekatan interdispliner. 


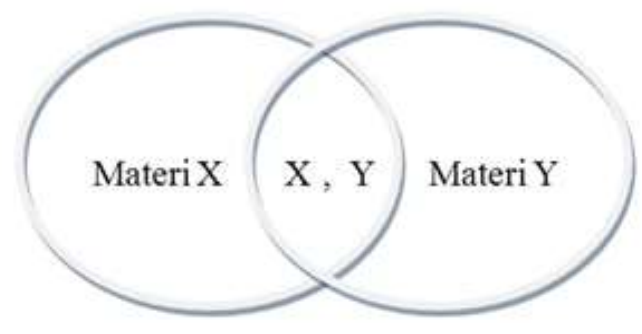

Gambar 1

Pendekatan Interdisipliner

Pendekatan selanjutnya pendekatan multidisipliner, yaitu suatu pendekatan yang mengacu kepada berbagai perspektif ilmu yang relevan. Pendekatan multidisipliner ini merupakan pengembangan suatu disiplin dengan memanfaatkan bantuan dari berbagai ilmu-ilmu lainnya, seperti: politik, ekonomi, manajemen, hukum, sosial, dan sebagainya. Pendekatan multidisipliner menyarankan kepada sejumlah ilmu, lebih dari dua ilmu yang berbeda untuk dipakai dalam menganalisis masalah yang sama (Fitri et al., 2019), atau istilah lain dari pendekatan multidisipliner, yaitu pendekatan dalam memecahkan suatu masalah dengan menggunakan berbagai sudut pandang banyak ilmu yang relevan dengan masalah yang sedang dicarikan solusinya (Sari \& Amin, 2020). Jika pendekatan multidisipliner ini diterapkan dalam kurikulum, maka akan menghasilkan novelty atau kebaruan teori dan metodologi yang dapat menjawab berbagai tantangan global dan memberi saran masukan strategis terhadap berbagai masalah kemanusiaan dan kemasyarakatan. Berikut pendekatan multidisipliner yang diterapkan pada prodi S2 PAI Pascasarjana IAIMNU Metro Lampung dapat dilihat dalam gambar berikut ini.

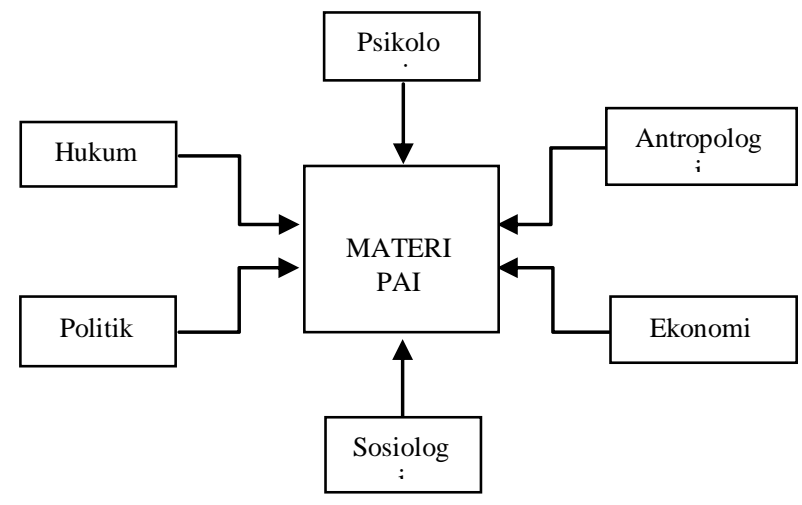

Gambar 2

Pendekatan Multidisipliner

Berdasarkan paparan di atas, menunjukan bahwa penerapan pendekatan interdisipliner dan multidisipliner pada Program Studi S2 PAI Pascasarjana IAIMNU Metro Lampung terlihat dari proses pembelajaran yang dilakukannya, di mana mahasiswa dibekali basic riset yang kuat sehingga nantinya mahasiswa mampu menghasilkan karya ilmiah yang mencerminkan interdisipliner dan multidisipliner, dengan demikian, wawasan pendidikan agama Islam menjadi lebih luas dengan berbagai perspektifnya.

\section{KESIMPULAN}

Berdasarkan uraian dan pembahasan di atas, dapatlah diambil suatu kesimpulan bahwa konstruksi distingsi keilmuan prodi S2 PAI telah diarahkan pada keunggulan menjadi pendidik, peneliti, dan praktisi yang mampu mendesain kurikulum Pendidikan Agama Islam berbasis Islam Nusantara melalui pendekatan interdisipliner dan multidisipliner. Paradigma pembelajaran pendekatan interdisipliner dan multidisipliner pada Prodi S2 PAI Pascasarjana IAIMNU Metro Lampung bertujuan untuk mengatasi berbagai permasalahan yang tidak dapat diselesaikan hanya dengan pendekatan monodisiplin saja, sehingga diperlukan pendekatan pembelajaran interdisipliner dan multidisipliner. Pendekatan interdisipliner dan multidisipliner ini merupakan sebuah perpaduan atau integrasi dari berbagai macam ilmu yang saling berkaitan hingga saling menembuas satu ilmu dengan ilmu yang lainnya.

\section{Daftar Pustaka}

Azizah, F. R. (2019). Mengembangkan Paradigma Integratif-Interkonektif Dalam Pendidikan Islam Di Perguruan Tinggi (Pendekatan Interdisipliner Dalam Studi Islam. Al-Tarbawi Al-Haditsah: Jurnal Pendidikan Islam, 4(2), Article 2. https://doi.org/10.24235/tarbawi.v4i2.5181

Creswell, J. W., \& Creswell, J. D. (2017). Research Design: Qualitative, Quantitative, and Mixed Methods Approaches. SAGE Publications.

Fitri, A. Z., Nasukah, B., \& Tayeb, A. (2019). Strategic Planning Model of Islamic Religious Higher Education (PTKI) in Indonesia. Jurnal Pendidikan Islam, 8(2), 287-308. https://doi.org/10.14421/jpi.2019.82.287-308

Iriany, I. S. (2014). Pendidikan Karakter sebagai Upaya Revitalisasi Jati Diri Bangsa. Jurnal Pendidikan Universitas Garut, 08(01), 32.

Jaenullah, J. (2018). Epistemologi Islam (Sebuah Konsep Islam Tentang Pengembangan Ilmu dan Gerakan Intelektual). At-Ta'lim: Media Informasi Pendidikan Islam, 17(2), 221. https://doi.org/10.29300/attalim.v17i2.1413

Marini, A., Safitri, D., Nuraini, S., Rihatno, T., Satibi, O., \& Wahyudi, A. (2020). Applying Model Of Mobile Web Based On Character Building In Teaching Learning Process To Improve Student Character. International Journal of Advanced Science and Technology, 29(06), 1121-1124.

Moleong, L. J. (2014). Metode Penelitian Kualitatif. PT Remaja Rosdakarya.

Musthofa. (2017). Pendidikan Islam Perspektif Humanisme-Pancasila. Jurnal Tarbiyah, $X X I V(1)$.

Nasution, K. (2017). Bepikir Rasional-Ilmiah dan Pendekatan Interdisipliner dan Multidisipliner dalam Studi Hukum Keluarga Islam. Al-Ahwal, 10(1), 13-21. 
Nino Indriyanto. (2019). Rancangan Bahan Ajar PAI Dengan Pendekatan Interdisipliner Di Perguruan Tinggi Umum (Studi Pengembangan Di Fakultas Keguruan Dan Ilmu Pendidikan Universitas Jember Dan Fakultas Ilmu Pendidikan Universitas Negeri Surabaya). Universitas Negeri Surabaya.

Putra, P. H. (2019). Tantangan Pendidikan Islam dalam Menghadapi Society 5.0. Islamika : Jurnal IlmuIlmu Keislaman, 19(02), 99-110. https://doi.org/10.32939/islamika.v19i02.458

Rahmat, R. (2019). Pendidikan Agama Islam Berwawasan Interdisipliner Sebagai Corak dan Solusi Pendidikan Agama Islam Era 4.0. Jurnal Pemikiran Keislaman, 30(2), 349-361. https://doi.org/10.33367/tribakti.v30i2.821

Rohmatika, R. V. (2019). Pendekatan Interdisipliner dan Multidisipliner Dalam Studi Islam. Al-Adyan: Jurnal Studi Lintas Agama, 14(1), 115-132. https://doi.org/10.24042/ajsla.v14i1.4681

Sari, R. M., \& Amin, M. (2020). Implementasi Integrasi Ilmu Interdisipliner dan Multidisipliner: Studi Kasus di Pascasarjana UIN Sunan Kalijaga Yogyakarta. Prosiding Konferensi Integrasi Interkoneksi Islam dan Sains, 2, 8.

Setyaningsih, R. \& Subiyantoro. (2017). Kebijakan Internalisasi Nilai-Nilai Islam Dalam Pembentukan Kultur Religius Mahasiswa. Edukasia: Jurnal Penelitian Pendidikan Islam, 12(1), 30 .

Subandi, S. (2020). Quality Development Model of Management Islamic Religious Higher Education of Nahdltul Ulama. Jurnal Iqra' : Kajian Ilmu Pendidikan, 5(2), 107-121. https://doi.org/10.25217/ji.v5i2.1195

Subandi, Choirudin, Mahmudi, Nizaruddin, \& Hermanita. (2018). Building Interactive Communication with Google Classroom. International Journal of Engineering \& Technology, 7(2.13), 460-463.

Sugiyono. (2017). Metode Penelitian Kuantitatif, Kualitatif, dan $R \& D$. CV. Alfabeta.

Umar, N. (2014). Konsep Hukum Modern: Suatu Perspektif Keindonesiaan, Integrasi Sistem Hukum Agama Dan Sistem Hukum Nasional. Walisongo: Jurnal Penelitian Sosial Keagamaan, 22(1), 157. https://doi.org/10.21580/ws.2014.22.1.263

Wahyudi, A., Salamun, S., Hamid, A., \& Choirudin, C. (2021). Strategi Pengelolaan Vocational Life Skill Pada Pendidikan Islam. Jurnal Manajemen Pendidikan Islam Al-Idarah, 6(1), 39-45. 